\title{
WHEN THE OBLIGATION TO BE NEUTRAL BECOMES THE RIGHT TO DISCRIMINATE: DISCURSIVE STRUGGLES OVER LGBT+ RIGHTS AT POLISH UNIVERSITIES
}

\author{
QUANDO A OBRIGAÇÃO DE SER NEUTRO SE \\ TRANSFORMA NO DIREITO DE DISCRIMINAR: \\ EMBATES DISCURSIVOS SOBRE OS DIREITPS LGBT+ EM \\ UNIVERSIDADES POLONESAS
}

\author{
Łukasz Pakuła* \\ Joanna Chojnicka**
}

\begin{abstract}
In this article, we discuss the narratives of struggle, resistance, and counter-resistance over the rights of the LGBT + community at several Polish universities, which remain unnamed in order to protect our informants. In particular, we look at the discourses of LGBT + groups struggling to establish or maintain organizations of various forms (from students' study circles to union-like institutions) within the context of internal university structure, Polish academic culture and current political developments in the country. This research draws on semi-structured in-depth interviews we conducted in the spring and summer of 2020. In our analyses of the interview material, we apply a multidisciplinary methodological framework combining CDA and narrative inquiry in order to examine linguistic phenomena participating in constructing a particular version of reality through text in talk. Such research design enables us to offer a case study of the difficulties and obstacles faced by LGBT + activists in the Polish academia the way they understand them, and of the resistance strategies they employ in this particular context. Our research shows a wide range of resistance strategies employed by the LGBT + community members that can be classified according to the scale of discriminatory practices they form a response to (systemic/individual discrimination) and the type of the response itself (group/individual response). On the basis of the discussed examples, our article offers an interagentive matrix of strategies of addressing LGBT + issues emerging within the Polish academic context.

Keywords: Polish universities; LGBT + community; resistance strategies; Critical Discourse Analysis; narrative inquiry; heteronormativity.
\end{abstract}

\footnotetext{
* Adam Mickiewicz University ;Poznań, Poland. 1.pakula@gmail.com

Orcid: https://orcid.org/0000-0003-0571-6019

** Adam Mickiewicz University ;Poznań, Poland. j.a.chojnicka@gmail.com

Orcid: https://orcid.org/0000-0002-2974-3110
} 


\section{RESUMO}

Neste artigo, discutimos as narrativas de embates, resistência e contra-resistência sobre os direitos da comunidade LGBT+ em várias universidades polonesas, cujos nomes não são fornecidos a fim de proteger os nossos informantes. Em particular, analisamos os discursos de grupos LGBT + que lutam para estabelecer ou manter organizações de várias formas (desde círculos de estudo de estudantes a instituições do tipo sindical) no contexto da estrutura interna das universidades, da cultura acadêmica polonesa e dos atuais desenvolvimentos políticos no país. Esta investigação baseia-se em entrevistas em profundidade semiestruturadas que realizamos na primavera e no verão de 2020. Nas nossas análises do material da entrevista, aplicamos um quadro metodológico multidisciplinar que combina ACD e investigação narrativa, a fim de examinar fenômenos linguísticos que participam na construção de uma versão específica da realidade por meio de texto em conversa. Tal concepção de investigação permite-nos oferecer um estudo de caso das dificuldades e obstáculos enfrentados pelos ativistas LGBT+ na academia polonesa, da forma como os entendem, e pelas estratégias de resistência que empregam neste contexto particular. A nossa investigação mostra uma vasta gama de estratégias de resistência empregadas pelos membros da comunidade LGBT+ que podem ser classificadas de acordo com a escala de práticas discriminatórias a que respondem (discriminação sistêmica/individual) e com o tipo de resposta em si (resposta de grupo/individual). Com base nos exemplos discutidos, o artigo oferece uma matriz interagentiva de estratégias de abordagem de questões LGBT+ emergentes no contexto acadêmico polonês.

Palavras-chave: universidades polonesas; comunidade LGBT + ; estratégias de resistência Análise Crítica do Discurso; investigação narrativa; heteronormatividade

\section{INTRODUCTION}

In this article, we discuss the narratives of struggle, resistance, and counterresistance over the rights of the LGBT+ community at several Polish universities, which remain unnamed in order to protect our informants. This work forms part of a larger research project on the discourses around LGBT+ issues in Polish academia, a project that is both unprecedented - academic discourses have rarely figured as the object of critical research, especially in Poland - and urgently necessary, due to the current anti-LGBT + turn taken by the Polish government, parts of the media and civil society. As the present special issue focuses on resistance, here we zoom in on the perspectives of LGBT+ groups struggling to establish or maintain organizations representing their (research) interests at universities, offering them a platform to tell their story of resistance and resilience in the form of semistructured in-depth interviews we conducted in the spring and summer of 2020. In our analyses of the interview material, we apply a multidisciplinary methodological framework drawing on CDA (Wodak \& Meyer, 2015) and narrative inquiry in order to examine linguistic phenomena that participate in constructing a particular version of reality through text in talk, and to reveal both sides' argumentative strategies as 
represented and interpreted by our interviewees. Such research design enables us to offer a case study of the difficulties and obstacles faced by LGBT + activists in Polish academia the way they understand them, and of the resistance strategies they employ in this particular context. Although our informants remain anonymous, and the universities they are affiliated with - unnamed, the case study can be read as emblematic of the social reality in Poland, which continues to re-invent itself as a nation based on traditional and conservative social norms. Nevertheless, we acknowledge the fact that our study is qualitative in nature and makes no pretense to representativeness of the LGBT + community, or Polish society for that matter, in toto. We hope that the article will have a practical value in offering illustrations and suggestions of how to resist discriminatory practices at universities and other institutions.

\section{SOCIO-POLITICAL CONTEXT OF THE STUDY}

2020 will undoubtedly go down in history as the year of the global COVID-19 epidemic. But under the conditions of general lockdown, amid concerns about the looming global economic crisis and the daily reports of new hotspots and recordbreaking numbers of new cases and deaths, a country at the eastern margin of the European Union - the Republic of Poland - has quietly marked 2020 with another kind of event that will probably not be so well remembered: it has officially become the worst country in the EU for the LGBT+ community to live in ${ }^{1}$.

In the Rainbow Europe country ranking of 2020, Poland has scored 15.84\%, coming in last out of all the 27 European Union member states. The EU overall score has been $48 \%$, with Malta scoring highest at $89.1 \%$.

Poland's shameful accomplishment has mostly gone unnoticed, with only a few commentators expressing their indignation (and probably more declaring satisfaction) on social media. But, truth be told, such outrage should be considered misplaced, because Poland has not, strictly speaking, fallen to the last place. It had always been at the bottom of the race; its being ranked as the worst is the result of other countries moving up.

Poland has been considered a notoriously homophobic country ever since it re-emerged on the global scene as an independent nation in the early 1990s. In 2006, Agnieszka Graff famously wrote that "Poles are a nation of homophobes, and proud of it" (2006: 449). Thirteen years later, according to the Public Opinion

1.https://www.rainbow-europe.org/country-ranking 
Research Center (Centrum Badania Opinii Publicznej) 2019 survey, still only 14\% Poles consider homosexuality to be a normal thing (CBOS 2019: 3). For a handful of scholars in Polish humanities and social sciences, including the authors of this article, this has been reason enough to devote their careers to LGBTQ-related issues (e.g. Kochanowski 2004, 2013, Kulpa \& Mizielińska (eds.) 2011, Chojnicka 2019, 2020, Pakuła et al. 2015, Pakuła 2019, Pakuła (ed.) 2021, Kłonkowska 2017, Majka-Rostek 2019, Nowak 2013). We had planned our research for this article before the Rainbow Europe ranking was published, and before - even more significantly - the presidential elections of 2020 instrumentalized the Polish LGBTQ community in the most distressing way, with pervading consequences. Thus - although regrettably- this article could not be better timed.

Despite the pandemic, the Polish government refused to postpone the presidential elections planned for May 2020, knowing very well that time was not working in favour of the incumbent conservative president Andrzej Duda. Eventually, unable to have the vote in May and faced with serious competition from a new candidate, Duda decided to mobilize right-wing and extreme rightwing voters by going after the LGBT + community. In one speech, he declared that "LGBT were not people - just ideology"2and in another promised to change the Constitution to make it illegal for same-sex couples to adopt children ${ }^{3}$. Duda won the election in the second round in July 2020 with $51.03 \%$, but the situation of the LGBT + community has never stopped deteriorating. It has already been noted in the past that Polish society's attitudes towards LGBT + worsen under the influence of discriminatory (and often outright hate) speech by politicians and other public figures (Mazurczak et al. 2019: 5). According to the surveys by the NGO Mitość nie wyklucza (Love does not exclude), public support for the formalization of same-sex relationships is - possibly due to this political pressure - currently on the decline $e^{4}$.

Because most universities are still in lockdown, it is difficult to say how these political developments will impact the status of the LGBT + community at Polish universities, the monitoring of which is a task for our future academic work. But Polish academia has functioned as the laboratory of conservative social experiments in the past. For example, in 2015, drawing on the discourse of the "ideology of gender" and thus evoking moral panics, the-then Minister for Further Education,

2. https://www.theatlantic.com/ideas/archive/2020/07/polands-rulers-manufactured-a-rainbowplague/614113/

3. https://www.theguardian.com/world/2020/jul/04/poland-president-plans-to-forbid-adoption-bysame-sex-couples

4. https://mnw.org.pl/rownosc-malzenska-2018/?fbclid=IwAR0GA3rjpwRXvTXplc6JcIDsdmiFL7y oujtNYdWc3yQY_nvf87EHq-UrueU 
Jarosław Gowin, pronounced gender studies incompatible with the common sense and Polish values. The same minister announced removing "lesbian and gay studies" journals from official journal lists published by his ministry. This troubling situation is further exacerbated by the newly coined discourses of "LGBT ideology" likened by powerful Catholic Church officials to a "rainbow plague", which have been materialized in 100 "LGBT-free zone" declarations espoused by local councils and are already resulting in the so-called chilling effect. However, to do justice to the Polish academic reality, we need to mention the recent scandal surrounding homophobic lectures of Ewa Budzyńska, a professor of Uniwersytet Śląski. After a complaint filed by students, the university ethics commissioner decided to issue a reprimand thus acknowledging the offence. Budzyńska, in protest against curbing her "freedom of speech", decided to quit her job at the university".

\section{THEORY, METHODS AND MATERIALS}

The questions of who, why, and under which circumstances defines what as a "political" or "social" matter are grist for the mill in Critical Discourse Analysis (CDA), which is concerned with the way discourse constitutes social reality: "it constitutes situations, objects of knowledge, and the social identities of and relationships between people and groups of people" (Fairclough and Wodak 1997: 258). Most centrally, CDA is interested in the relations of power. The struggle for power, especially in the modern world, takes place on the platform of discourse ("to secure power, it makes sense to persuade everyone else that what you want is also what they want", Wareing 2004: 38), where groups compete for the right to name, label and define. Our case study provides a striking illustration for this theory - here, different interest groups associated with the university compete to define issues, events and projects either as "scientific" or "political" and the outcome of this struggle can have severe, real-life consequences, for example in the form of silencing certain research topics and promoting others or perpetuating systemic erasure of non-heteronormative ${ }^{7}$ agents from the academic landscape.

5. https://wiadomosci.dziennik.pl/polityka/artykuly/505753,jaroslaw-gowin-o-reformie-nauki-iszkolnictwa-wyzszego-likwidacja-studiow-gejowskich.html

6. https://katowice.naszemiasto.pl/skandal-na-uniwersytecie-slaskim-prof-ewa-budzynska/ar/c1 7515661

7. Non-heteronormativity here is understood as an umbrella term encapsulating not only homosexuality but all forms of identity expression which do not fall into the conception of heteronormative identities. For instance, one of our informants self-identifies as a trans* person. 
CDA has always, and understandably so, concentrated on hegemonic, mainstream discourses of the dominating elites in order to expose how language participates in maintaining the social status quo. CDA scholars argue - in the truly Marxist spirit which remains one of the strongest theoretical foundations of the field - that an awareness of these mechanisms is necessary in order to change the existing power relations. This article takes a different approach, present, but less widespread within CDA (Martin 2004), giving voice to the representatives of underprivileged groups and a platform for their resistance. Known under the label of Positive Discourse Analysis (PDA), this subbranch of CDA shifts the focus from emphasizing injustice to highlighting alternatives (Bartlett 2010). It strengthens, but also goes beyond the more traditional CDA work in offering discourses that can contribute to positive social change (Bartlett 2012).

In order to collect data for the study, we have conducted five semi-structured interviews with representatives of LGBT + organizations (or activists trying to establish such organizations) at four Polish universities. All interviews took place between May and August 2020 and due to the pandemic-related restrictions, all were conducted remotely using the Zoom application. This enabled us to record the interviews for easier processing and analysis. Ethics consent form, specifying our obligations to use the recordings for research and educational purposes only and to guarantee our interviewees' anonymity, was supplied and explained and verbal consent was acquired before the recording began.

The interviews ranged in length from 36 minutes 42 seconds to 1 hour 20 minutes 19 seconds, giving us in total 4 hours 44 minutes 50 seconds of data. Table 1 below offers detailed information on the interviews, as well as the interviewee's codes used throughout the text of this article.

Table 1. Information on the interviews conducted for the study

\begin{tabular}{|c|c|c|c|c|}
\hline interview date & interview length & interviewee & university & interviewee's code \\
\hline May 23, 2020 & $01: 20: 19$ & 1 & A & A \\
\hline June 6, 2020 & $00: 36: 42$ & 2 & B & 2B \\
\hline August 7, 2020 & $01: 06: 45$ & 3 & $\mathrm{C}$ & 3C \\
\hline August 11,2020 & $00: 55: 21$ & 4 & $\mathrm{D}$ & 4D \\
\hline August 14,2020 & $00: 45: 43$ & 5 & $\mathrm{~A}$ & 5A \\
\hline
\end{tabular}

The interviews were conducted with four representatives of the teachingresearch staff, mainly with doctoral degrees and in permanent positions, all of whom were recruited via the so-called snowball method as well as directly reaching out to LGBT+ organizations within the Polish academic venues. While three of 
our informants are full-time academics, one is a student, and another one - the founder of an LGBT + research group with extensive experience of researching the situation of non-heteronormative university students currently pursuing a nonacademic career. It is our understanding that these individuals form Communities of Practice (CoPs) understood as "an aggregate of people who come together around mutual arrangement in some common endeavour" (Eckert \& McConnellGinet, 1992, p. 464), although quite frequently, due to lack of physical proximity, such groups can be also initially perceived in terms of imagined communities until their members form meaningful bonds and engage in political activity (Anderson, 1983). Their shared identity is not limited to merely being part of an academic non-heteronormative community, but importantly incorporates inherent political agency, i.e. conscious activism, within these ranks.

All our interviewees identify as members of the LGBT + community, but not all of them openly present as such at their university. In the text, we refer to all respondents using the singular they/them pronouns in order to avoid explicit feminine and masculine gendering.

We asked all interviewees the same set of six relatively broad questions, starting with a request to assess the general situation of the LGBT + community at their university and the institution's anti-discrimination standards and procedures, before moving on to discuss the LGBT + organization they represent in more detail. In each case, however, we pursued individual strands that developed out of these questions, as long as the time that our interviewees had at their disposal permitted.

We did not ask our interviewees explicit questions concerning resistance strategies, in order to make sure that our own interests and interpretations are not imposed on them. We wanted to know if they themselves think of their activities as "resistance" in the first place, and give them the opportunity to talk about these practices in their own way and on their own terms. We believe, following Lyons \& LaBoskey (2002) that a narrative can constitute a scaffolding of discursive practices and thus be telling of its author's lived experiences. Narratives as such possess the capability of capturing idiosyncratic discursive strategizing for resistance in a highly hierarchical academic lived reality. This was especially relevant in the case of interviewees $1 \mathrm{~A}$ and $5 \mathrm{~A}$, who represent the same university and the same LGBT+ organization. Content-wise, their narratives differ to a significant extent, offering us two divergent yet complementary perspectives on the meaning-making strategies regarding the same issues.

The analytical toolkit for the acquired data assumed principles of narrative analysis, where the goal is not to obtain factual information, not to arrive at 
"objective" knowledge of an event or situation, but to let the interviewees construct their versions of events, to get a picture of how they create meaning within their life-world and how they make sense of events through the interpretive lens of their value systems. Following Connelly \& Clandinin:

People shape their daily lives by stories of who they and others are and as they interpret their past in terms of these stories. Story, in the current idiom, is a portal through which a person enters the world and by which their experience of the world is interpreted and made personally meaningful. Narrative inquiry, the study of experience as story, then, is first and foremost a way of thinking about experience. Narrative induiry as a methodology entails a view of the phenomenon. (Connelly \& Clandinin, 2006, p. 479)

The first set of questions - about the general situation of non-heteronormative members of the university and examples of possible discrimination - motivated narratives about the structural axes of inequality and discrimination within an institution from a particular, relatively powerless perspective. These narratives provided cues about structures of prejudice underlying power relations in the respective institutions. The second set of questions concerning LGBT+ organizations that struggle to exist within such institutions made it possible for our respondents to assume the role of a social actor resisting discrimination and prejudice. In this part of the data, we identified examples of what we interpreted and labelled as "discursive strategies of resistance". While, as can be expected, most practices under this label involve language in some shape or form, not all of them are inherently discursive, in the sense of the struggle for the power to define mentioned above. As we will show, however, in many cases resistance involves discursive redefining, reframing or recontextualizing of the same practice or event in order to make it more acceptable to university stakeholders and officials.

Another issue to keep in mind is that while the LGBT + organizations under study here are represented by concrete people, fulfilling specific roles within the university, it is much less clear what (or who?) "the university" is, who represents it, or who has the right to speak in its name. When we talk about "university officials", we often think of the administrative staff, but, as one of our interviewees rightfully pointed out, administrative staff members occupying roles lower in the pecking order, such as venue management staff, are often among the rather underprivileged groups in the university hierarchy, and can also be non-heteronormative, i.e. at the receiving end of the institution's discriminatory practices. The Rector and Rector's office definitely seem most legitimized to speak on behalf of the university, but in practice, many of the issues we explore in our study do not even make it to the Rector's desk. For example, in the notorious case of a Polish university agreeing to participate in a "march for life" - the Rector's office claimed that the Rector never 
knew that the patronage had been authorized. Researchers with work experience at different universities will know that there are very divergent regulations concerning who can represent the institution in the media. But also within one university, the same researcher is sometimes encouraged to speak to the media on behalf of it (with full credentials), and sometimes asked to speak "as a private person". Obviously, all these possibilities - just like the difference between "scientific" and "political" can also be used in manipulative ways in order to silence or promote particular people, views, events or projects.

\section{GENERAL SITUATION OF THE LGBT+ COMMUNITY AT POLISH UNIVERSITIES}

There is no statistical data concerning the nation-wide situation of the LGBT + community at Polish universities. Only one institution publishes reports on the situation of its LGBT + students every five years (so far, in 2011 and 2016) on the basis of questionnaires distributed online to both heteronormative and non-heteronormative students. The more recent report found that $40 \%$ of respondents had witnessed LGBTQ students being discriminated by other students, in the form of verbal abuse, physical violence, destruction of property, hate mail etc. (Jej Perfekcyjność 2016: 19). Discriminatory behaviour of university teachers and technical staff was less frequent and included derogatory and insulting remarks towards the LGBTQ community (not individual students) as a whole (Jej Perfekcyjność 2016: 29). Another, rather problematic statistic comes from the NGO sector. Kampania Przeciw Homofobii (Campaign Against Homophobia) regularly publishes reports about the "social situation of LGBTA persons in Poland ${ }^{8 \prime}$, but the most recent one is from 2017 and mentions universities only in terms of locations where particular (including discriminatory or abusive) practices take place. For example, according to the report, $73.3 \%$ of LGBTA persons "hide their orientation [or gender identity] at school or university" (Świder \& Winiewski 2017: 8). When it comes to the experiences of violence, $12.9 \%$ of verbal attacks on LGBTA persons take place at school/university, while $18.1 \%$ of sexual violence - in public spaces, including schools, universities, restaurants and sport clubs (Świder \& Winiewski 2017: 83). Unfortunately, these formulations make it impossible to discern the exact share of universities in such statistics. What is more, lumping schools and universities together may obscure important differences between them. School is obligatory, brings together children from all possible social contexts

8. https://kph.org.pl/publikacje_kph/ 
and backgrounds, and fulfills different social functions than a university; previous research has found that Polish schools serve to socialize children to (re)produce heteronormative and heterosexist discourses (Chojnicka \& Pakuła, 2021). On the other hand, higher education is elective and universities grant their students and staff more liberty in various respects. At times, universities can be conceptualized as safe spaces ${ }^{9}$.

This impression is generally shared by our interviewees:

(1) jedno jest pewne - na uniwersytecie jest lepiej niż poza uniwersytetem 'one thing is certain - it is better at the university than outside of the university' $(3 \mathrm{C})$

While our study participants emphasized that there may be differences across various faculties and levels in the university hierarchy (students, doctoral students, postdocs, professors, as well as administrative staff of differing levels), the general situation of the LGBT+ community in their own local context was evaluated as good, relatively speaking. It seems to be general knowledge that certain faculties or programs are more tolerant, liberal or progressive (for example, English studies or cultural studies), and they attract LGBT + students and researchers in numbers that are reportedly visibly higher than in other places. Under such conditions, an open and tolerant attitude is expected and thus gross homophobia occurs rarely. This does not mean that there are no people with homophobic views; rather, they are aware of the fact that expressing such views is not welcome. This applies especially to students:

(2) większość studentów ma pozytywne postrzeganie osób niebeteronormatywnych (...) wręcz oczekują sygnatów wyraźnych od kadry, że (...) uniwersytet, że nasz wydziat konkretnie jest postępowy i akceptujący

'the majority of students has a positive perception of non-heteronormative people (...) they even expect clear signals from the staff that (...) the university, that our faculty in particular is progressive and accepting' (5A)

The same respondent offered a much telling - if guesstimated - breakdown of the university employees' attitudes, which we quote here in fragments in order to save space. In their opinion, $10 \%$ of university employees are przychylne, aprobujące, przyjazne, zainteresowane 'in favour, approving, friendly, interested' towards non-

9. https://www.nytimes.com/2019/08/29/opinion/safe-spaces-campus.html 
heteronormative people. The vast majority - around 50\% - are approving, but passive: they do not harm but also do not help the non-heteronormative community. A further $10 \%$ are people who

(3) traktuje nieheteronormatywność jako odstępstwo od normy, wynik mody, czasami może jakaś skaze moralna

'treat non-heteronormativity as a deviation from the norm, the result of fashion, sometimes maybe some sort of moral defect' $(5 \mathrm{~A})$

Another $10 \%$ of employees do not voice their opinions, but they are potentially "hostile". Finally, 20\% seem to be afraid - and

(4) im się należy najwięcej jakiejś edukacji i uświadamiania

'they deserve the most education and awareness-raising' (5A)

Our respondents could not remember any cases of overt verbal or physical violence directed against concrete individuals. The discrimination reported on is much more subtle and covert. This is in line with previous CDA research on prejudice (van Dijk 1997). Our interviewees talked about frequent jokes (not about a specific person, but the LGBT+ community in general), people using LGBT+ labels as slurs, expressing comments concerning (e.g. gender-nonconforming) appearance or behaviour, or refusing to use preferred pronouns and names for transgender persons. We also heard about at least one case in which a person's queerness was politicized and used against them in an election to a university body (3C, see also Conclusions). What is important, such covert discrimination is rarely practiced by students towards other students, or by teachers towards students, but more often by university employees (teachers and researchers) in relation to other employees. This could be a blind spot of our study, as we talked to only one student, or a consequence of the position of the other interviewees in university hierarchy - it is possible that students choose not to share their experiences with them, especially if they do not openly present as LGBT+ themselves. At some universities, no cases of discrimination on the basis of sexual orientation or gender identity have ever been filed through official university channels. Such state-ofaffairs is, however, more likely due to the fact that procedures filing such instances are unclear, if known by the interested parties at all, as reported by $5 \mathrm{~A}$.

Jokes and comments mentioned above are a frequent feature of "water-cooler conversations" in the presence of LGBT + individuals who have not come out to their colleagues. Once an LGBT+ person comes out, such banter becomes less 
frequent, but the atmosphere also changes and the relations between employees turn "colder", more official and formal. Some colleagues become more "restrained" (1A). Both the climate where the LGBT + community is not taken seriously and only mentioned in a joking manner, and the apparently punitive cold-shoulder treatment people receive when they do come out, function as gate-keeping mechanisms to prevent the majority of LGBT + individuals from being out at the university, in spite of the generally open and tolerant atmosphere.

The situation could be completely different in faculties or programs known as conservative and less LGBT + friendly, but information about possible incidents rarely reaches our respondents. A program that was mentioned more than once in the interviews as a rather close-minded and intolerant space was pedagogy. Respondent 4D mentioned a pedagogy teacher who continuously referred to nonheteronormative people as "perverted" during her lectures. Students objected, but nothing was done about it.

The situation of transgender persons constitutes a special case. Here, while often there is no problem with teachers and administrative staff addressing transgender students using correct names and pronouns, university facilities and technologies prove resistant to change. One respondent told us about the initiative to designate a toilet in their building as gender-neutral. This caused a scandal when an administrative employee contacted some right-wing media, lamenting "the discrimination of heterosexual people and gays and lesbians, who would only be allowed to use one toilet" (4D). This anecdote illustrates the common discursive trope of the majority being discriminated against, as well as a complete lack of understanding of transgender issues (see below).

Our final remarks in this section concern contact with university and faculty authorities (decision makers). This domain of activity creates particular challenges relevant to a discussion about resistance strategies. While the climate of interactions between students, teachers and researchers, and administrative staff at local levels can, of course, affect the wellbeing of LGBT + people and seriously impact their performance and prospects at university, it is the authorities who have the actual power to promote or penalize particular behaviours and practices. At the same time, a positive attitude towards LGBT + presented by the authorities can "send an important message" about the values that members of the university community are expected to share $(1 \mathrm{~A})$. An official declaration by the Rector condemning the politicization of LGBT+ around the presidential elections in summer 2020 was an important act of solidarity for the university's non-heteronormative community (4D). 
Our respondents agreed that the authorities treated them differently than people perceived as heteronormative. While it may not be outright discrimination, it could be considered unequal. This refers both to openly LGBT+ people and those working on LGBT+-related issues. Examples include reluctance to allow an open lecture about rainbow families during a science festival, opposition to the founding of an LGBT psychology science club, denial of the existence of discrimination - often by university bodies created to ensure equal treatment! - or rejection of applications for funds for LGBT +-related activities. Resistance to such practices will be discussed at length in the next section.

Our interviewees also felt that openly LGBT + people were often assumed to be trouble-makers, treated as untrustworthy and suspicious by the authorities. Frequently, when they turned to their superiors for, say, assistance in terms of providing university room for extra-curricular activities, they were faced with a "talk-down" conversation where they were discursively constructed as "suspicious of subversive intentions". While it is possible that this is caused by a person's assertiveness and persistence rather than just being LGBT+ $(5 \mathrm{~A})$, it still paints the university in a negative light, as a place where defending one's values, standing one's ground is penalized.

University decision makers seem to wish to "protect" the university space and its image from LGBT+-related, "controversial" topics, while being (perceived as) "politically correct" at the same time. Some interviewees talked about being invited to meetings to discuss a problematic topic of an open lecture or a conference with visibly uncomfortable university decision makers unable to even pronounce the word bomosexuality. They mentioned uncomfortable smirks and whispers at faculty board meetings where their work was discussed. This pervading atmosphere of embarrassment and unease can further diminish the wellbeing of LGBT + people and the willingness of other people to present as allies. It also shows that nonheteronormativity remains a heavy social taboo in Poland, even in spaces commonly believed to be open, tolerant and progressive, and above all, spaces whose agendas should be knowledge- and science-driven.

\section{LGBT+ RESISTANCE STRATEGIES AT POLISH UNIVERSITIES}

It is clear from the previous discussion that unequal treatment of, or discrimination against, the LGBT + community at Polish universities ranges from systemic discrimination of the whole group to unique acts directed against specific individuals. This shapes practices of resistance. As one of our respondents 
said, quoting Michel Foucault, "no resistance exists outside of the system" (4D). Resistance is always re-active, a response to the status quo considered no longer bearable or acceptable.

In this section, we make an attempt at grouping LGBT + resistance strategies we found in our interviewees' narratives according to the kind of discrimination they react to on the scale from system to practice, and according to the scale of response, from group to individual. This creates a two-dimensional matrix represented roughly in Figure 1 below:

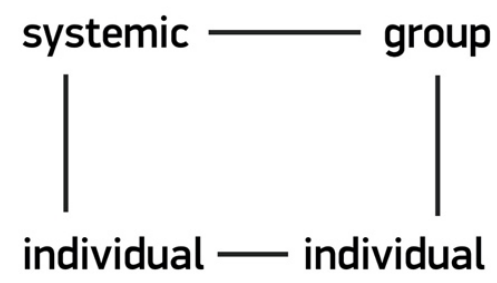

Figure 1. Matrix of types of resistance strategies

In what follows, we will discuss in more detail the examples of these types of resistance strategies found in our interviews.

\section{$\underline{\text { Systemic/group }}$}

It should be mentioned first of all that work is the only domain that offers protection from discrimination on the basis of sexual orientation by the Polish law. In theory, this law protects LGBT + university employees (but not students or PhD candidates). In addition, mostly due to the need to conform to EU regulations, many universities in Poland have established an institution that is the system's own response to discrimination: a Rector's proxy for equal treatment, and/or an equal rights commission. These authorities can be contacted in case of discrimination on the grounds of ethnicity, nationality, religion, gender, sexuality, etc. In practice, this rarely happens, as - if known to the academic community at all - the process is long, tedious and potentially retraumatizing. It is also not always clear that such possibilities exist and how to reach them.

The proxy's activities rarely address the LGBT + community. At one university, the proxy did attend a conference on homophobia they were invited to and even praised it (1A); but the same person later attempted to block the creation of an LGBT + organization under pressure from right-wing groups. It thus appears 
that the LGBT + community often has to work in resistance to the very institution created to help them (among others).

At another university, the proxy's post was offered to one of our interviewees, in recognition of their feminist activism (4D). But the post came with neither a salary (all teaching and research staff are required to devote $10 \%$ of their working time to administrative tasks) nor a budget. If, then, the proxy's work could be considered here as resistance from within the system, the lack of funding effectively blocks it (counter-resistance). Our interlocutor, despite these palpable systemic obstacles, is planning to draw on the symbolic status of their new role and seek EU grants for their activities. This is a way to circumvent the university's decision makers and secure funding that is independent of university politics; additionally, EU funding comes with a certain degree of prestige that makes it hard for local authorities to undermine the planned activities.

The most common systemic/group resistance strategy is to establish student LGBT + organizations within university structures. The reason for this is that only student organizations are allowed by the Polish higher education law. All the universities considered here either have $(\mathrm{A}, \mathrm{B}, \mathrm{C})$ or are planning to establish (D) such organizations. The obvious drawbacks are that university employees are not represented (doctoral students may in theory join such groups, but in practice it rarely happens), that funding is limited, and that student organization activities are monitored and controlled by university authorities.

Respondent 3C had a story that illustrates this point. Their LGBT+ student organization, whose profile is more research- than activism- or intervention-driven, wanted to organize a three-hour seminar about pornography. This was downright forbidden, the organization's website was taken down, and the event's scientific committee members, including professors and postdocs, were summoned to the Rector's office to explain themselves. The group responded by organizing a fullday conference on pornography in the social sciences, drawing way more attention than the originally planned event would have. Here, resistance to the authorities' censorship turned out to be productive, not merely reparative.

It is an interesting case also because a lot of opposition towards the group seems to be coming from the students' government. It is this body that grants yearly funding to student organizations, and around the time of the pornography seminar scandal, the LGBT + group's applications were rejected repeatedly without a straightforward motivation.

There was even some opposition to the organization being founded in the first place. On the day of signing the founding declaration, there was a small protest 
staged by several students, claiming that they were being denied their free speech rights. This is an example of a common discursive strategy of the (new)right, where keywords of the liberal discourse - tolerance, discrimination, buman rights - are recontextualized and reappropriated. Discrimination thus becomes something that the heterosexual majority suffers from, and free speech is understood as the right to exercise hate speech. This observation goes hand in hand with critical inquiries into the concept of "free speech" which can be thought as working to the benefit of the elites of newly established liberal democracies (Khiabany \& Williamson, 2015).

What is very interesting, the right-wing opposition constructed the group as activist, maybe even militant, although it was established on the basis of academic interests in queer theory. The same happened to the LGBT psychology study group founded at university A. During a faculty board meeting, the point was raised that the group would be used for "subversive" activities. Other arguments against establishing the group included the fear that the term LGBT psychology was discriminatory towards the LGBT + community, and security concerns - the group's members could be at risk of attack. In spite of these arguments the board voted for establishing the group.

\section{Systemic/individual}

The inherently discriminatory system predetermines many individual decisions that need to be managed during one's university career. The basic one seems to be whether to come out as LGBT+ or not. Our interviewees shared their individual coming out stories, casting them as strategic choices (strategia dtugoterminowa 'longterm strategy') without being prompted by us to do so.

One option is to secure one's position at the university before coming out:

(5) aby uzyskać jakaśs pozycję, trzeba się trochę zakamuflować... się przyczaić i przeczekać 'in order to obtain some sort of position, one needs to camouflage yourself... lay low and wait' (4D)

When interacting with others, one's communicative style in this case should be non-confrontational, aiming at reaching consensus or compromise. It may also be beneficial or necessary to make strategic decisions concerning one's research interests. Young doctoral students and postdocs may feel forced to choose "safer", less "controversial" topics and avoid terms such as gender or queer in their work, especially since the term gender in Polish seems to have been "lost" to right-wing ideologues. 
Sometimes such strategizing concerns the actual content of research, but other times it constitutes a surface reframing of titles of dissertations, lectures or seminars with the content intact. Respondent $4 \mathrm{D}$ told us that when they offered a seminar entitled Gender in culture, they faced a lot of opposition from their students, having to struggle at the beginning of each semester to recapture the term from the right-wing framing that the students left high school with. After changing the title to Stereotypes and prejudice in texts of culture, the opposition stopped, although the content of the seminar remained the same. This resonates with Pakuła's (2019) experience of carrying out an externally-funded project featuring both "gender" and "sexuality" in its title. In order to bypass potentially hazardous opposition on the part of schools, both of these concepts were paraphrased which engendered no negative repercussion on the part of the project's primary and secondary educational partners.

At the other end are individuals who "smuggle" LGBT+ content into seemingly unrelated lectures and seminars, for example, an English writing class or a seminar about fuzzy systems (5A). This works to normalize non-heteronormativity by integrating it into everyday discursive practice rather than presenting it as a problem or a matter of debate. Morrish \& Sauntson, 2007 (pp. 87-111) reflect on introducing ambiguous sexual identities into a class on English phonetics. By choosing an indefinite anaphoric pronoun, the lesbian teacher decided to reveal her lesbian identity to the queer student population and conceal it from the heteronormative cohort. Morrish (2002) sees this act as a discursive resistance against lesbian identity erasure in her research domain. She compares her situation with this of Grundy (1995) who, in his book on pragmatics, draws on his heterosexually imbued familial examples and comments:

What strikes this lesbian linguist is Grundy's taken-for-granted entitlement to reveal these familial and marital contexts and details - even to publish them. For me to do the equivalent would at the very least raise eyebrows in the classroom, and, more probably, in the current climate of discussion of Section 28 in Britain, lead to accusations that I was 'promoting' bomosexuality. The result for me bas been self-censorship and a kind of look-abead reparsing strategy, by which I can adapt my examples in order to eradicate their pro- noun content. (Morrish, 2002, p. 186)

Another strategy is to be out from the very beginning of one's academic career. This choice, however, requires one to be assertive, resilient, and able to stand one's ground. As mentioned before, being openly LGBT + was indexical of being a trouble-maker, which means that whatever they do will be considered problematic or questionable. As a result, they will interact with university/faculty authorities more often than their colleagues read as heterosexual. This is partially to be accounted for by the process of content substitution, i.e. heterosexual mention 
is perceived as non-content while the occurrence of marked mentions of nonheteronormative is considered marked content (Ripley et al., 2012). One of our interviewees emphasized the importance of setting the tone of such conversations, not accepting being cast in the defensive position or framing their activities as problematic (1A).

The final systemic/group resistance strategy we will introduce here is activism outside academia. Those who are not out at their university may find their "tribe" in an NGO, while those openly LGBT + may strategize to involve social actors from other domains - mainly schools and NGOs - in pursuit of Action Research projects (see Burns, 2019). One interviewee claimed that the triad of academia, school and NGOs is where real social change takes place (4D). In our respondents' narratives, solidarity with other oppressed groups, most notably women (e.g. in the context of their struggle over reproductive rights) surfaced frequently. Solidarity is also something that is awaited from others, especially in positions of prestige. Around the presidential elections of 2020, the authorities of many universities were expected by our respondents to issue official declarations of support for the LGBT + community. As a side note, it may be mentioned that during university elections at one of the institutions we looked at, the incumbent Rector who was also running was forbidden to issue such a declaration of support by the election committee. Solidarity (with LGBT + people) is invariably construed as a political issue. This correlation gains special significance in Poland, where the Solidarity movement of the 1980s played an important role in abolishing the socialist regime. Today, Solidarity is still active as a trade union, also at universities, embodying and active lobbying for right-wing, (neo)conservative values. Solidarity activists frequently ventilate their anti-LGBT + sentiments and take measures to block LGBT + initiatives, a lived experience which also constituted an important part of 4D's narrative.

\section{Individual/group}

Communities of Practice can come together to resist an individual act of discrimination or oppression. This was the genesis of the blueprinted LGBT+ organization at university A, where some employees wished to react to a sermon delivered by a Catholic bishop in which he infamously likened LGBT + people to a "rainbow plague" and a neo-Marxist thought which aims to conquer Polish souls ${ }^{10}$. This was later enforced by his letter read out by many priests at Sunday masses in the Kraków area where he attacked LGBT+ communities as sick,

10.https://oko.press/kosciol-lgbt-marsz-bialystok/ 
perverted, deviant and anti-Polish ${ }^{11}$. This message was supported by the Academic Citizens' Club (Akademicki Klub Obywatelski), an obscure right-wing organization led by a retired professor that made a claim to speak on behalf of the local academic community comprising, among others, individuals from several universities (leading to a discussion on who can represent the university and speak in its name, relevant to our project). A resistance letter was written and signed by the university’s LGBT+ employees specifically opposing strategic utilization of university's authority to legitimize views based on personal bias, prejudice and stereotypes in contrast to research, state-of-the-art knowledge and mutual respect. It was important to the initiators that the letter be signed only by non-heteronormative people, excluding their allies. It was a strategic choice to speak in their own name, to performatively and discursively bring a Community of Practice into existence - a community in the sense of a group acting together in a common cause, united in lived experience in the ivory tower and willing to engage in political action, rather than just a list of persons united by a characteristic.

This act of resistance sparked off plans to establish an organization representing such a community, not merely a student study group, but more like a union. This way, a group reaction to an individual discriminatory act morphed into a reaction to systemic discrimination, illustrating how the types of resistance strategies suggested above are not distinct, mutually exclusive varieties, but rather idealized models of a much more complicated reality. This testimony also points out to the organic nature of enacting strategies and performing resistance. Viewed as such, they should be seen as highly reactive unpredictable and tailored to the hereand-now needs yet with an understanding that the targets they set for themselves are long-run and need to be based within the localized system of oppression.

The authorities seemed opposed to the idea of founding such an LGBT + organization. A legal assessment was issued, stating that such a body would constitute discrimination against heterosexual populations of the university's community. According to the Polish higher education law, university employees cannot establish other organizations than trade unions, so the argument was that an LGBT + trade union would discriminate against other employee groups. The project's initiators commissioned an independent legal assessment, which made a solid case for refuting the one issued by university legal office. According to the most recent update on the situation, the Rector has given the go-ahead to the initiative. Motivated by a discursive act of discrimination whose goal was to shame

11.https://krakow.wyborcza.pl/krakow/7,44425,25248648,ofensywa-abp-jedraszewskiego-napisaldo-wiernych-list-o-lgbt.html 
the LGBT+ community into silence, the organization, if successfully established, will be the first political-cum-activist university body representing LGBT+ teachers, researchers, administrative staff and students in Poland.

In closing, it is worth mentioning that for the first time, the burden of resistance is being taken off the students' shoulders: students were not involved in the legal dispute, but will be, of course, welcome to join the organization once it is set up. While the student groups mentioned above do benefit from the young people's energy and idealism, engaging in them may be putting them at risk, e.g. of being failed by a homophobic professor.

\section{Individual/individual}

This type involves an individual's act of resistance towards another individual's act of discrimination; it is thus most likely to involve discursive strategies. We have already mentioned that our respondent's open lecture for a science festival was rejected due to its "controversial" content. Rather than withdrawing the lecture altogether or changing its content, they decided to make the title more neutral and innocent. This is definitely an act of resistance, because it was clear that the authorities were uncomfortable about the lecture's content, not merely its title, and that by presenting the lecture the way it had been originally planned, the respondent defied the authorities. In a similar vein, one of the authors of this article submitted a grant proposal to a Polish government funding bodies which explicitly featured "LGBT" and "sexuality" in the title. The proposal was rejected at the first stage of evaluation due to ideologically motivated reasons, one of them bore striking semblance to the university's legal assessment, i.e. that overt focus on nonnormative identities has the potential to skew research data and cast the majority in unfavorable light. Another attempt at submission was made, this time strategically reformulating the title so that it mirrors the content of the proposal yet does not feature the two tabooed concepts. Importantly, the remainder of the proposal was left intact. This time the proposal made it to the second round of assessment. Despite the fact it was not successful on this occasion, the motivation departed from the original one, this time centering around technical and methodological issues, however ill-founded. It seems thus, that strategizing in this aspect of one's academic activity is possible and can be fruitfully pursued.

Often a seemingly trivial act of speaking may be subject to conscious strategizing. LGBT + people frequently have to react to local instances of verbal discrimination or abuse: should they try to remain calm, show understanding and a willingness to explain the simplest issues, or have they the right to lose temper and demand an apology? This happens in situations where many people do not 
even see a problem at all and cannot sympathize with the amount of emotional labour that goes into making such decisions over and over again. Our respondents talked about having to "pick their battles": sometimes it is strategically necessary to let discrimination pass unaddressed in order to focus on what is achievable and productive.

The personal/personal vector of resisting oppression also surfaced from $3 \mathrm{C}^{\text {'s }}$ narrative when they were recollecting an event featuring an "unsung hero" (cicha bohaterka). Since the vice-rector of the university denied access to the requested venue, their academic event needed to be moved to a room of a much smaller size. Having spotted this, the head of the building "did her utmost" (stanęta na rzęsach, lit. 'stood on her eyelashes') to find an alternative. Thus, the unexpected assistance came to the rescue of the conference: an individual strategic intervention resisted systemic and hierarchical oppression. This example testifies to the fact that not all acts of resistance need to come from a given Community of Practice and needs to be carefully planned - quite to the contrary, it can be spontaneous.

\section{CONCLUSIONS AND FUTURE PROSPECTS}

The fragmented reality of remote teaching and collaboration in the COVID-19 reality can be a curse, but also a blessing. Lack of in-person encounters can contribute to dismantling of emotional bonds by imposing an unprecedented amount of social distancing. On the other hand, however, CoPs, such as nonheteronormative populations of university staff, can come together in joint pursuit of common causes irrespective of the location and local affiliation. Also student initiatives potentially enjoy a greater likelihood of reaching university stakeholders as tedious and time-consuming processes of, for instance signature collection, are now simplified in the virtual reality. At the beginning of the 2020/21 academic year, Radio Eska informed that trans-identified students would be able to use their preferred name and pronouns on the university's intranet system ${ }^{12}$. This was made possible due to a fruitful cooperation between TęczUJ, a Jagiellonian University's LGBT + student organization, and the Department of Safety and Equal Treatment at the university (Dział ds. Bezpieczeństwa i Równego Traktowania) which resulted in designing a patch to be used at this particular university. In order to avoid instances of hoaxes, the university decided that such pronoun and name alterations

12.https:/www.eska.pl/krakow/transplciowi-studenci-uj-wybiora-jakie-imie-zobaczy-wykladowca-touznanie-podmiotowosci-28-09-aa-NuSS-YppP-NXeF.html 
would be made possible following an interview with university officials trained to lead such meetings. This is a sign of progress in the treatment of trans* and non-binary student cohorts. Regrettably this is a localised instance, as the system patch is unlikely to be of use at the other universities across the country. Yet, on a positive note, University of Silesia (Uniwersytet Śląski) in Katowice might follow suit, as reported by Gazeta Wyborcza ${ }^{13}$. Future research, therefore, could focus on strategies of resistance by establishing rapport with university officials willing to hear non-heteronormative students out and incorporating their desiderata into official policies.

Another, somewhat underexplored field, concerns queer investigations of Linguistic Landscapes (LLs) at Polish academia. Following Milani (2013, p. 2), we recognize the centrality of studies which "have highlighted the importance of transcending the purely linguistic element of public texts so as to also grasp their multimodal and multi-semiotic nature" but are similarly disappointed with the little attention that "sexuality" has received within this paradigm of inquiry. A notable exception is Motschenbacher's (2020) exploration of the LL of Florida's Wilton Drive which, as per the researcher's findings, constitutes a homonormative space privileging gay males over other genders or sexualities. Based on the narratives of our study participants we see room for illuminating research into the LL aspect of the academia and the campus (see also Karioris et al., 2018). Canakis \& KerstenPejanić (2016), in turn, having investigated LLs in Athens and Belgrade, pin down the differences in embedding sexuality-related issues. While LL of Athens targets the political system as oppressive, Belgrade's activist efforts are more indirect and subtle. Regrettably, as similar themes surfaced in our research project, we realized that little, if any, research on LL on educational premises has been done. In our interviews, participant $2 \mathrm{~B}$ remembers the sight of posters of their LGBT + university organization which had been torn off at certain faculties. Such activities can be viewed as strategies of heteronormative gate-keeping at these locations. Erasure is not the only strategy of homophobic and transphobic activity. Meme-like stickers of participant $3 \mathrm{C}$ wearing a wig and full make-up distributed across university venues served as a heteronormative deterrent by means of the accompanying caption:

(6) Czy chcesz aby tak teraz wygladaty imprezy studenckie?

'Do you want student parties to look like this now?' (3C)

13.https://katowice.wyborcza.pl/katowice/7,35063,26352857,us-pozwoli-transplciowym-studentomna-zmiane-imienia-oferuje.html? fbclid = IwAR3J5vZ40vRw50tg-MJ9L5JNAuJFTfF83bTQBqM1ju9-4X0D7dv37Xh8y8 
This wording is a symbolic semantic-semiotic demarcation line of what is allowed and desired and what is to be seen as unwelcome on university premises. This message was amplified by the strategic timing of sticker distribution, i.e. student council elections. It clearly surfaces, then, that portraying a given individual as non-heteronormative was meant to cast them in unfavorable light thus reducing their chances of getting elected. Such narratives are telling of the default acutely heteronormative academic linguistic landscape which only occasionally is interrupted by queer semiotics.

Our findings clearly point to an interagentive matrix of strategies of addressing LGBT + issues emerging within the Polish academia. Although based on a relatively modest sample of participants, it seems to have a wide potential of applicability to various venues and micro socio-political contexts. It is our hope that similar lines of inquiry will be pursued with regard to other educational venues to elucidate success stories of strategizing efforts aiming at ensuring systemic policies embracing diversity and equality. Another important line of inquiry is to look beyond students and academic staff when considering research on academia. Agents who often go unnoticed, such as janitors, cleaners, low-ranking admin staff also deserve attention of all researchers concerned with AR leading to a more just and balanced academic reality.

\section{REFERENCES}

Anderson, B. (1983). Imagined Communities: Reflections on the Origins and Spread of Nationalism. Verso.

Bartlett, T. (2012). Hybrid voices and collaborative change: Conceptualizing positive discourse analysis. London: Routledge.

Bartlett, T. (2010). Towards intervention in Positive Discourse Analysis. In C. Coffin, O'Halloran, K., \& Illis, T. (Eds.), Applied Linguistics Methods: A Reader (pp. 133-147). Abingdon: Routledge, The Open University.

Burns, A. (2019). Action Research in English Language Teaching: Contributions and Recent Developments. In J. Voogt, G. Knezek, R. Christensen, \& K.-W. Lai (Eds.), Second Handbook of Information Technology in Primary and Secondary Education (pp. 1-15). Springer International Publishing. https://doi.org/10.1007/978-3-319-58542-0_52-1.

Canakis, C., \& Kersten-Pejanić, R. (2016). Spray-Canned Discourses Reimagining Gender, Sexuality, and Citizenship Trough Linguistic Landscapes in the Balkans. In S. Goll, 
M. Mlinarić, \& J. Gold (Eds.), Minorities Under Attack: Othering and Right-wing Extremism in Southeast European Societies (pp. 129-160). Harrassowitz Verlag.

CBOS 2019. Stosunek Polaków do związków homoseksualnych. Komunikat z badań ur 90/2019. Warszawa: Fundacja Centrum Badania Opinii Publicznej.

Chojnicka, J., \& Pakuła, Ł. (2021). Polish LGBT teachers talking sexuality: Glocalised discourses. In Ł. Pakuła (Ed.), Linguistic perspectives on sexuality in education: Representations, constructions, and negotiations. (pp. 0-0). London: Palgrave Macmillan.

Chojnicka, Joanna. 2020. Transition Narratives on Polish Trans Blogs: A Discursive Colonization Approach. In: Godovannaya, M., M. Neufeld, S. Shoshanova, K. Wiedlack (eds.) Solidarity, Place and Power: queer-feminist Struggles and the East/West Divide. Bern: Peter Lang, 201-227.

Chojnicka, Joanna 2019. Homosexuality in Latvian and Polish parliamentary debates 1994-2013: A historical approach to conflict in political discourse. In: Jeffries, L., J. O’Driscoll (eds.) The Handbook of Language in Conflict. London: Routledge, 103-127.

Connelly, F. M., \& Clandinin, D. J. (2006). Narrative inquiry. In J. L. Green, G. Camilli, \& P. Elmore (Eds.), Handbook of complementary methods in education research (pp. 477-487). Lawrence Erlbaum.

Eckert, P., \& McConnell-Ginet, S. (1992). Think practically and look locally: Language and gender as community-based practice. Annual Review of Antbropology, 21, 461-490.

Fairclough, Norman \& Ruth Wodak 1997. Critical discourse analysis. In T.A. Van Dijk (Ed.), Discourse Studies. A multidisciplinary introduction, vol. 2. Discourse as social interaction (pp. 258-284). London: Sage Publications.

Graff, Agnieszka 2006. We are (not all) homophobes - a report from Poland. Feminist Studies 32 (2): 434-49.

Grundy, P. (1995). Doing Pragmatics. Edward Arnold.

Jej Perfekcyjność 2016. Wyobcowane, wyobcowani. Raport z badań nad sytuacją osób LGBTQ studiujacych na Uniwersytecie Warszawskim edycja 2016. Warszawa: Queer UW.

Karioris, F. G., Haywood, C., \& Allan, J. A. (2018). An Education in Sexuality and Sociality: Heteronormativity on Campus. Lexington Books. 
Khiabany, G., \& Williamson, M. (2015). Free speech and the market state: Race, media and democracy in new liberal times. European Journal of Communication. https://doi. org/10.1177/0267323115597855.

Lyons, N., \& LaBoskey, V. K. (Eds.). (2002). Narrative Inquiry in Practice: Advancing the Knowledge of Teaching. Teachers College Press.

Kłonkowska, Anna. 2017. Płeć: dana czy zadana? Strategie negocjacji (nie)tożsamości płciowej w Polsce. Gdańsk: Wydawnictwo Uniwersytetu Gdańskiego.

Kochanowski, Jacek. 2004. Fantazmat ZróżNICowany. socjologiczne studium przemian tożsamości gejów. Kraków: Wydawnictwo Universitas.

Kochanowski, Jacek. 2013. Socjologia seksualności: marginesy. Warszawa: Wydawnictwo Naukowe PWN.

Kulpa, Robert, and Joanna Mizielińska, eds. 2011. De-centring western sexualities: Central and Eastern European perspectives. Farnham: Ashgate.

Majka-Rostek, Dorota 2019. Medialne coming outy polskich artystów-strategie wizerunkowe. Culture Management/Zarządzanie w Kulturze 20 (2), 181-197.

Martin, James R. 2004. Positive discourse analysis: Solidarity and change. Revista Canaria de Estudios Ingleses 49: 179-200.

Mazurczak, Anna, Marcin Mrowicki \& Milena Adamczewska-Stachura 2019. Sytuacja prawna osób niebeteroseksualnych i transptciowych w Polsce. Międzynarodowy standard ochrony praw człowieka osób LGBT i stan jego przestrzegania z perspektywy Rzecznika Praw Obywatelskich. Warszawa: Biuro Rzecznika Praw Obywatelskich.

Milani, T. M. (2013). Whither linguistic landscapes?: The sexed facets of ordinary signs. Tilburg Papers in Culture Studies. https://research.tilburguniversity.edu/en/publications/ whither-linguistic-landscapes-the-sexed-facets-of-ordinary-signs

Morrish, L. (2002). The case of the indefinite pronoun: Discourse and the concealment of lesbian identity in class. In L. Litosseliti \& J. Sunderland (Eds.), Gender identity and Discourse analysis (pp. 177-192). John Benjamins.

Morrish, L., \& Sauntson, H. (2007). New perspectives on language and sexual identity. Palgrave Macmillan. 
Motschenbacher, H. (2020). Walking on Wilton Drive: A linguistic landscape analysis of a homonormative space. Language \& Communication, 72, 25-43.

Nowak, Samuel. 2013. Seksualny kapitat. wyobrażone wspólnoty smaku i medialne tożsamości polskich gejów. Kraków: Wydawnictwo Universitas.

Pakuła, Ł. (2019). Befriending the risk(s) in language, sexuality, and education research: Blueprinting for a taxonomy of risks. In C. Danjo, I. Meddegama, D. O’Brien, J. Prudhoe, L. Walz, \& R. Wickasono (Eds.), Online Proceedings of the 51st Annual Meeting of the British Association for Applied Linguistics: Taking Risks in Applied Linguistics (pp. 86-90). York St John University.

Pakuła, Ł. (ed.). (2021). Linguistic perspectives on sexuality in education: representations, constructions, and negotiations. London: Palgrave Macmillan.

Pakuła, Ł., J. Pawelczyk, \& J. Sunderland. (2015). Gender and sexuality in English language education: Focus on Poland. London: British Council.

Ripley, M., Anderson, E., McCormack, M., \& Rockett, B. (2012). Heteronormativity in the University Classroom Novelty Attachment and Content Substitution among Gayfriendly Students. Sociology of Education, 85(2), 121-130.

Świder, Magdalena \& Mikołaj Winiewski 2017. Situation of LGBTA Persons in Poland. 2015-2016 Report. Warsaw: Campaign Against Homophobia.

Van Dijk, Teun A. 1997. What is political discourse analysis? In J. Blommaert, \& C. Bulcaen (Eds.), Political Linguistics (pp. 159-177). Amsterdam: John Benjamins.

Wodak, R., \& Meyer, M. (Eds.). (2015). Methods of Critical Discourse Studies (Third edition). London: SAGE.

Wareing, Shân 2004. What is language and what does it do? In L. Thomas, S. Wareing, I. Singh, \& J. Stilwell Peccei (Eds.), Language, society and power: An introduction (pp. 1-16). London: Routledge.

Recebido: 16/10/2020

Aceito: 4/12/2020

Publicado: 7/12/2020 